\title{
Purification and Properties of Proteinase with an Optimum pH at 8.0 from Gouda- Type Cheese and Its Comparison with Milk Proteinase
}

\author{
Kunio YamauChI, Keiji Igoshi* and Shuichi Kaminogawa \\ Faculty of Agriculture, The University of Tokyo, \\ Bunkyo-ku, Tokyo 113 \\ ${ }^{*}$ Faculty of Agriculture, Kyushu Tokai University, \\ Choyo-son, Kumamoto-ken 869-14
}

(Received December 25, 1986)

\begin{abstract}
The proteinase was purified from Gouda-type cheese by combination of ammonium sulfate fractionation, and CM-Sephadex and DEAE-cellulose chromatographies. The purified enzyme exhibited homogeneity in disc electrophoresis, and was most active at $\mathrm{pH}$ 8.0. Diisopropyl-fluorophosphate inactivated the enzyme, which was also inhibited by $\mathrm{N}-a$-tosyl-L-lysine-chloromethylketone and soybean trypsin inhibitor. The molecular weight of the enzyme was 100,000 . Several fragments were generated by treating $\alpha_{\mathrm{s} 1}$-casein with the enzyme. The decomposed products of $\beta$-casein by the enzyme had an equal mobility to $\gamma$ casein ( $\beta-\mathrm{CN}$ (f 29-209), $\beta-\mathrm{CN}$ (f 106-209) and $\beta-\mathrm{CN}$ (f 109-209)). These properties of the enzyme were similar to those of alkaline proteinase in milk, and therefore, the enzyme is regarded as alkaline proteinase in milk.

Jpn, J.Zootech. Sci., 58 (6) : 516-527, 1987

Key words : cheese, Gouda-type cheese, proteinase, milk proteinase
\end{abstract}

Since protein breakdown during cheese ripening is an indispensable process for developing the flavor and texture of cheese, the mechanism has been extensively studied $^{1)}$. The decomposed products, which were derived from caseins, have been isolated from Gouda and Cheddar cheeses ${ }^{2,3)}$, and the occurrence of materials like $\gamma$ casein ( $\beta-\mathrm{CN}$ (f 29-209), $\beta-\mathrm{CN}$ (f 106-209) and $\beta-\mathrm{CN}$ (f 109-209)) was confirmed ${ }^{3 \text { ). }}$ Several authors assumed that these products resulted from milk proteinase (plasmin) action on $\beta$-casein ${ }^{3-8)}$. To confirm the existence of milk proteinase in cheese, it is necessary to compare the properties of the purified enzyme from cheese with that of milk proteinase.

We extracted the proteinase with an optimum $\mathrm{pH}$ at 8.0 from Gouda-type cheese and found that $\gamma$-casein like ( $\beta-\mathrm{CN}$ (f 29-209), $\beta-\mathrm{CN}$ (f 106-209) and $\beta-\mathrm{CN}$ (f 109 209)) decomposed products were generated by treatment with the enzyme ${ }^{9)}$. In this paper, we purified the enzyme from Gouda-type cheese and compared its properties with alkaline milk proteinase. 


\section{Materials and Methods}

\section{Materials}

Ovomucoid was purified from product of Miles Laboratories. Diisopropyl-fluorophosphate (DFP) and soybean trypsin inhibitor (STI) were obtained from Sigma Chemical Company. CM-Sephadex, Sephadex G-150 and the standard kit for estimating the molecular weight from gel filtration were products of Pharmacia Fine Chemicals. DEAE-cellulose was from Seikagaku Kogyo. $\beta$-Lactoglobulin was prepared by the method of AschANFFENBURG ${ }^{10)}$, and all other reagents were of guaranteed grade.

\section{Cheese}

Gouda-type cheese ${ }^{9)}$ ripened for 5 months, which was a kind gift from Snow Brand Milk Products Co., was used for the experiments.

\section{Casein}

Casein was precipitated from skim milk at $\mathrm{pH} 4.6$ by adding $1 \mathrm{~N} \mathrm{HCI}$ at room temperature, the precipitate being washed with distilled water and lyophilized. $\alpha$ s1 and $\boldsymbol{\kappa}$-casein were purified by the method of ZITTLE and CUSTER ${ }^{11)}$, and $\beta$-casein was purified by the method of Fox and GuINEY ${ }^{12}$.

\section{Determination of proteolytic activity}

The activity of the proteinase was determined according to the method previously reported ${ }^{9)}$, the proteolytic activity being expressed in terms of the difference in optical density (O.D.) between 0 and $24 \mathrm{hr}$. The specific activity was calculated by dividing the proteolytic activity by the absorbance of the enzyme solution at $280 \mathrm{~nm}$.

5. Preparation of alkaline milk proteinase

Alkaline milk proteinase was purified from unfractionated casein by using dimethylformamide according to the method previously reported by YAMAUCHI and KAMINOGAWA ${ }^{13)}$.

\section{Determination of the molecular weight}

The enzyme and standard protein solution were applied to a column $(2.6 \mathrm{~mm}$ dia. $\times 80 \mathrm{~mm}$ ) of Sephadex G-150 that had previously been equilibrated with $0.05 \mathrm{M}$ tris$\mathrm{HCI}$ buffer at $\mathrm{pH} 8.0$, and elution was with the same buffer. Ribonuclease A, chymotrypsinogen A, ovalbumin, bovine serum albumin and aldolase were used as standard proteins for the molecular weight determination. The eluted proteins of the enzyme were determined by measuring the proteolytic activity in the effluent.

\section{Polyacrylamide gel electrophoresis (PAGE) of hydrolized casein}

One $\mathrm{m} l$ of the enzyme solution (purified proteinase or alkaline milk proteinase),

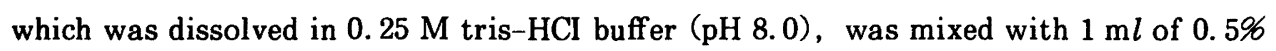
fractionated casein solution dissolved in the same buffer. The mixture was incubated at $30^{\circ} \mathrm{C}$ for a definite time. After the incubation, the reaction mixture was dissolved in an equal volume of $0.13 \mathrm{M}$ tris- $\mathrm{HCI}$ buffer containing $8 \mathrm{M}$ urea, $20 \%$ glycerol and $10 \%$ $\beta$-mercaptoethanol. After heating in boiling water for $5 \mathrm{~min}$, the sample was kept in a refrigerator until slab-PAGE analysis. Slab-PAGE was performed according to the 
procedure of O'FARREL using 7.5\% acrylamide gel containing 4.5 M urea and trisglycine ( $\mathrm{pH} \mathrm{8.6)}$ as the electrode buffer ${ }^{14)}$. Disc gel electrophoresis ( $\mathrm{pH} \mathrm{4.6,7.5 \%}$ acrylamide) was by the method of REISFELD et $a l^{15)}$. Gouda-type cheese was treated for analysis of PAGE as follows. Cheese $(50 \mathrm{~g})$ was homogenized with $150 \mathrm{ml}$ of cold distilled water in a polytron PT for $1 \mathrm{~min}$ and the homogenate was kept for $2 \mathrm{~min}$. After the cream on the surface was removed, homogenate was lyophilized. The lyophilizate was used for PAGE.

\section{Results}

\section{Purification}

Gouda-type cheese $(600 \mathrm{~g})$ was suspended in $0.05 \mathrm{M}$ acetate buffer (pH 4. 0, 2, 200 $\mathrm{ml}$ ) and the suspension was homogenized in a Polytron PT (Kinematica, Switzerland) for $2 \mathrm{~min}$. The homogenate was stood for $5 \mathrm{~min}$, and the cream was removed. After adjusting the $\mathrm{pH}$ to 4.0 , the homogenate was shaken for $1 \mathrm{hr}$ to extract the proteianse from Gouda-type cheese. After centrifuging the homogenate at 8,000 rpm for $30 \mathrm{~min}$, the supernatant $(1970 \mathrm{~m} l)$ was used as the starting material for purifying the enzyme.

Solid ammonium sulfate was added to the crude extract up to $20 \%$ saturation. The $20 \%$ saturated solution was allowed to stand at $4^{\circ} \mathrm{C}$ for $10 \mathrm{hr}$ with stirring and was then centrifugated at $8,000 \mathrm{rpm}$ for $30 \mathrm{~min}$. The supernatant fraction was dialyzed against $0.05 \mathrm{M}$ acetate buffer ( $\mathrm{pH} 4.0$ ). After centrifuging the dialysate, the supernatant $(2,820 \mathrm{ml}$ ) was concentrated to $250 \mathrm{ml}$ by Hollow Fiber DC-2 (Amicon Co., Ltd.) and then applied to a column $(5.2 \mathrm{~mm}$ dia. $\times 52 \mathrm{~mm})$ of $\mathrm{CM}-$ Sephadex that had been equilibrated with $0.05 \mathrm{M}$ acetate buffer ( $\mathrm{pH} \mathrm{4.0}$ ). The enzyme was eluted in $20 \mathrm{ml}$ fractions by a linear gradient of sodium chloride concentration ( 0 to $1.5 \mathrm{M})$ in the same buffer (data not shown). The active fractions were pooled and desalted by dialysis against distilled water, and then lyophilized. Lyophilized sample was dissolved

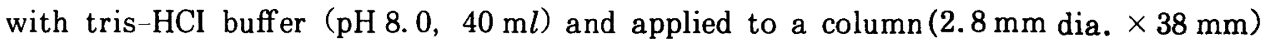
of DEAE-cellulose equilibrated with the same buffer. Linear-gradient elution was performed with increasing an concentration of $\mathrm{NaCl}$ from 0 to $0.3 \mathrm{M}$ in the same buffer. Proteinase activity was recovered in the unabsorbed fraction (Fig. 1). The active fractions were pooled and dialyzed against distilled water before being

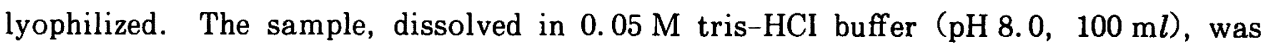
applied to a column $(2.8 \mathrm{~mm}$ dia. $\times 38 \mathrm{~mm})$ of $\mathrm{CM}$-Sephadex equilibrated with $0.05 \mathrm{M}$ tris-HCI buffer ( $\mathrm{pH} \mathrm{8.0)}$ ). Linear-gradient elution was performed with an increasing concentration of $\mathrm{NaCl}$ from 0 to $0.5 \mathrm{M}$ in the same buffer. Proteinase activity was found in fractions 48 to 56 (Fig. 2). These fractions were pooled and used for the experiment on the properties of the enzyme. The enzyme showed almost a single band in electrophoresis with polyacrylamide gel at pH 4.0 (Fig. 3). A summary of the purification method for the proteinase is shown in Table 1.

Effect of temperature and $\mathrm{pH}$ on the enzyme activity

The effects of temperature and $\mathrm{pH}$ on the enzyme activity were examined by the standard method, except that the temperature and buffer solutions were different. The 


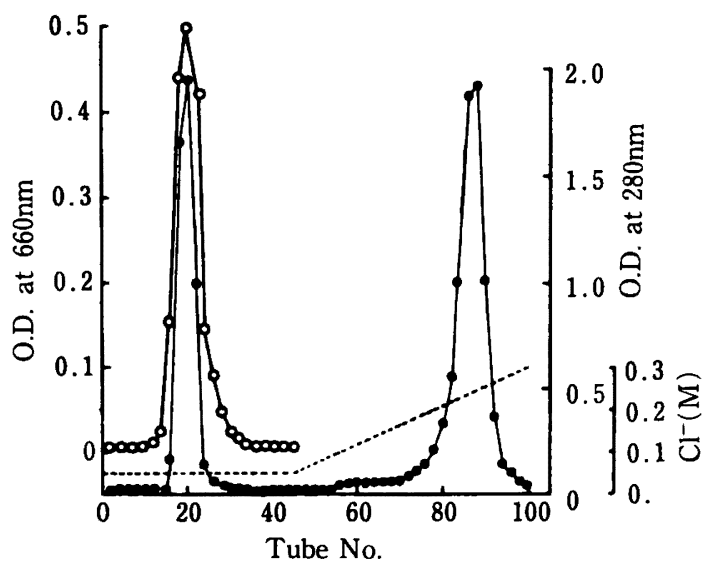

Fig. 1. DEAE-cellulose chromatography of the proteolytic fraction obtained by CM-Sephadex chromatography. The fractions from No. 16 to 25 were pooled. $\mathrm{O}-\mathrm{O}$, proteolytic activity $(0 . D$. at $660 \mathrm{~nm})$; (O.D. at $280 \mathrm{~nm}) ; \cdots \cdots, \mathrm{Cl}^{-}$concentration.

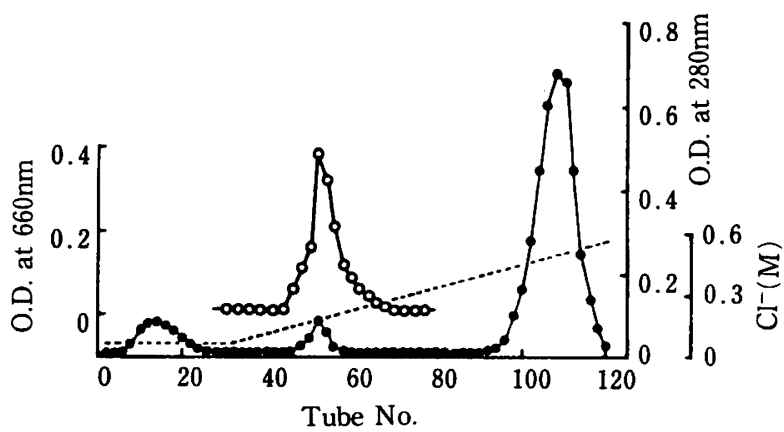

Fig. 2. Rechromatography of the proteolytic fraction on CM-Sephadex. The fractions from No. 48 to No. 56 were pooled. $\bigcirc-O$, proteolytic activity (O.D. at $660 \mathrm{~nm}) ;-$, protein (O.D. at $280 \mathrm{~nm}) ; \cdots \cdots, \mathrm{Cl}^{-}$ concentration.

optimum temperature for enzyme activity was found to be about $40^{\circ} \mathrm{C}$ (Fig. $4 \mathrm{~A}$ ) and the optimum $\mathrm{pH}$ at 8.0 (Fig. $4 \mathrm{~B}$ ). A sharp decrease in activity was observed as the $\mathrm{pH}$ deviated from the optimum level, this level being the same as described in the preceding paper").

Effect of heat and $\mathrm{pH}$ on the enzyme stability

The enzyme preparation was incubated with $0.05 \mathrm{M}$ tris-HCI buffer ( $\mathrm{pH} \mathrm{8.0)}$ at various temperatures for $10 \mathrm{~min}$, and the remaining activity were measured. As Fig. 5 A shows, enzyme activity was fairly heat stable and $50 \%$ of the enzyme activity remaining after heating at $90^{\circ} \mathrm{C}$ for $10 \mathrm{~min}$. After incubating the enzyme preparation with tris-HCI and phosphate buffers of various concentrations (final buffer concentraion, $0.02 \mathrm{M}$ ) at $20^{\circ} \mathrm{C}$ for $20 \mathrm{hr}$, each of the mixtures was diluted 5-fold with 0.1 


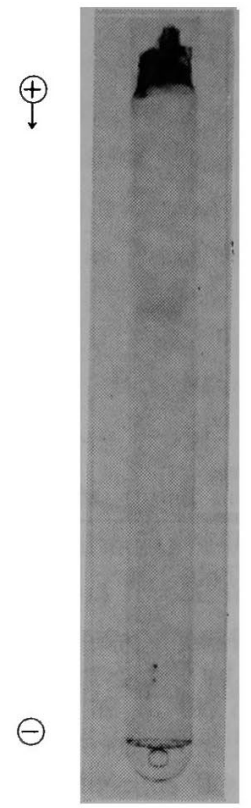

Fig. 3. Polyacrylamide gel electrophoretic pattern ( $\mathrm{pH} \mathrm{4.0)}$ of the purified enzyme. The method of REISFELD ${ }^{15}$ was used.

Table 1. Summary of purification

\begin{tabular}{lcc}
\hline \multicolumn{1}{c}{ Step } & ${\text { Specific } \text { activity }^{\text {a) }}}$ & Yield of activity $^{\text {c) }}$ \\
\hline Extract fraction & $0.024(1)^{\text {b) }}$ & 100 \\
Ammonium sulfate supernatant & $0.135(5.6)$ & 79 \\
CM-Sephadex & $0.390(16.3)$ & 29 \\
DEAE-cellulose & $0.644(26.8)$ & 25 \\
CM-Sephadex & $2.890(120.4)$ & 1.7 \\
\hline
\end{tabular}

a), Specific activity was calculated by dividing the proteolytic activity by the absorbance of the sample at $280 \mathrm{~nm}$. b), Figures in parenthesis indicate the purification based on extract fraction. c), Yield of activity (\%) was based on total activity of extract fraction

$\mathrm{M}$ tris-HCI buffer and the remaining activity was measured. The enzyme activity was stable in the $\mathrm{pH}$ range of 6.0 to 9.0 (Fig. $5 \mathrm{~B}$ ).

Effect of metal ions and reagents on the enzyme activity

The effect of some metal ions on the enzyme activity was examined, the results being in Table 2. The enzyme was weakly inhibited by $\mathrm{Ag}^{2+}, \mathrm{Zn}^{2+}$ and $\mathrm{Hg}^{2+}$, but not any other metal ions. The effect of some reagents on the enzyme activity was also examined, the results being shown in Table 3. The purified enzyme was completely inhibited by STI and significantly by DFP and TLCK. Ovomucoid, $\beta$-lactoglobulin 

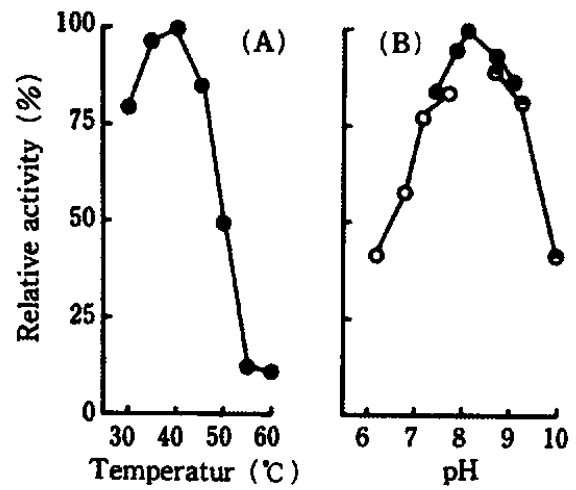

Fig. 4. Effect of temperature (A) and $\mathrm{pH}$ (B) on the enzyme activity. One $\mathrm{ml}$ of the enzyme solution and $1 \mathrm{ml}$ of $1 \%$ casein solution were mixed and mixture was treated as described in the text. Following buffers were used, $\mathrm{O}-\mathrm{O}$, phosphate buffer; $-\mathrm{O}$, tris$\mathrm{HCl}$ buffer ; $\Theta-\Theta$, glycine- $\mathrm{NaOH}$ buffer.

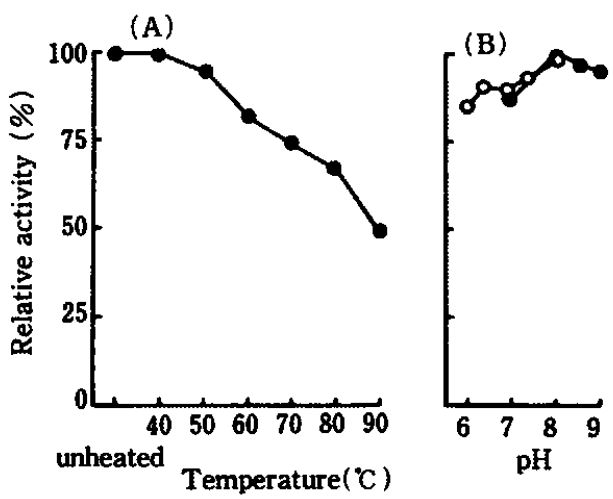

Fig. 5. Effect of temperature (A) and pH (B) on the enzyme stability. The enzyme solution was preincubated at various temperature for $10 \mathrm{~min}$ (A) and at $20^{\circ} \mathrm{C}$ for $20 \mathrm{hr}$ at fixed $\mathrm{pH}(\mathrm{B})$, and then the remaining activity was assayed.

$O$, phosphate buffer.

and TPCK had no effect on the enzyme activity. The enzyme was not also inhibited by PCMB, mono-iodoacetic acid, EDTA and $\alpha-\alpha^{\prime}$-dipyridyl.

Molecular weight

Fig. 6 shows the results of a molecular weight determination of the enzyme by gel filtration using Sephadex G-150. The molecular weight of the enzyme was about 100,000 .

Changes in the PAGE pattern of casein fractions ( $\alpha_{s-1}, \beta$-and $\kappa$-casein) by the enzyme

Changes in the PAGE pattern of casein fractions by the enzyme are shown in 
Yamauchi, IgOSHI and Kaminogawa

Table 2. Effect of metal ions on enzyme activity

\begin{tabular}{ccc}
\hline \hline Metal ions & $\begin{array}{c}\text { Concentration } \\
(\mathrm{mM})\end{array}$ & $\begin{array}{c}\text { Relative activity } \\
(\%)\end{array}$ \\
\hline None & 1 & 100 \\
$\mathrm{Mg}^{2+}$ & 1 & 100 \\
$\mathrm{Ca}^{2+}$ & 1 & 93 \\
$\mathrm{Mn}^{2+}$ & 1 & 98 \\
$\mathrm{Fe}^{2+}$ & 1 & 100 \\
$\mathrm{Ag}^{2+}$ & 1 & 34 \\
$\mathrm{Zn}^{2+}$ & 1 & 30 \\
$\mathrm{Hg}^{2+}$ & 1 & 34 \\
\hline
\end{tabular}

The enzyme solution was preincubated with metal ions for $10 \mathrm{~min}$ and then the remaining activity was assayed.

Table 3. Effect of inhibitors on enzyme activity

\begin{tabular}{lcc}
\hline \hline \multicolumn{1}{c}{ Inhibitors } & $\begin{array}{c}\text { Concentration } \\
(\mathrm{mM})\end{array}$ & $\begin{array}{c}\text { Relative } \\
\text { activity (\%) }\end{array}$ \\
\hline None & 1.0 & 100 \\
DFP & 1.4 & 5 \\
TLCK & 1.0 & 6 \\
Ovomucoid & $200^{*}$ & 95 \\
STI & $40^{*}$ & 0 \\
$\beta$-Lactoglobulin & $500^{*}$ & 99 \\
TPCK & 0.2 & 101 \\
PCMB & 0.1 & 102 \\
Monoiodacetic acid & 1.0 & 98 \\
EDTA & 1.0 & 100 \\
$\alpha-\alpha^{\prime}$-dipyridyl & 0.5 & 108 \\
\hline
\end{tabular}

${ }^{*}, \mu \mathrm{g} / \mathrm{m} l$; The enyme solution was preincubated with the inhibitors for $10 \mathrm{~min}$ and then the remaining activity was assayed.

Figs. $7 \mathrm{~A}, 8 \mathrm{~A}$ and $9 \mathrm{~A}$. For comparison, changes of the casein fractions by alkaline milk proteinase were studied at the same time (Figs. $7 \mathrm{~B}, 8 \mathrm{~B}$ and $9 \mathrm{~B}$ ). Accompanying the degradation of $\alpha_{\mathrm{s}_{1}}$ - casein, several decomposed products appeared in front of the band corresponding to $\alpha_{s}$-casein after $24 \mathrm{hr}$ of incubation, and one clear band (band 1) with a lower mobility than $\alpha_{\mathrm{s}} 1^{-}$casein appeared (Fig. $7 \mathrm{~A}$ ). Similar changes in the $\alpha_{\mathrm{s} 1^{-}}$casein band were observed when the alkaline milk proteinase acted on $\alpha_{\mathrm{s}} \mathrm{s}^{-}$ casein (Fig. 7 B). The mobility of band 1 was same as that of band $\mathrm{m}-1$ generated by treating alkaline milk proteinase. $\beta$-Casein disappeared during the incubatin, and four new products (bands 2, 3, 4 and 5) were generated by treating $\beta$-casein with the enzyme (Fig. $8 \mathrm{~A}$ ). Similar changes were observed when the alkaline milk proteinase acted on $\beta$-casein (Fig. $8 \mathrm{~B}$ ). The two bands $\mathrm{m}-2$ and $\mathrm{m}-3$ with low mobility, which appeared just above the slot, correspond to $\gamma$-casein ( $\beta-\mathrm{CN}$ (f 29-209), $\beta-\mathrm{CN}$ (f 106209) and $\beta-\mathrm{CN}$ (f 109-209)) band. The mobility of bands $2,3,4$ and 5 was equal to 


\section{Proteinase from Gouda-Type Cheese}

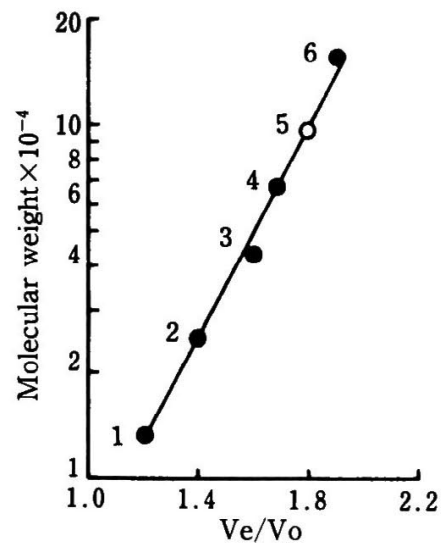

Fig. 6. Molecular weight determination of the enzyme by Sephadex G-150 chromatography. The column $(2.6 \mathrm{~mm}$ dia. $\times 80 \mathrm{~mm})$ was eluted with $\mathrm{pH} 8.0,0.05 \mathrm{M}$ tris-HCl buffer. 1 , ribonuclease $A ; 2$, chymotrypsinogen $A ; 3$, ovalbumin ; 4, bovine serum albumin; 5 , the enzyme; 6 , aldolase; Ve, elution volume of protein; Vo, void volume of column determined with blue dextran.

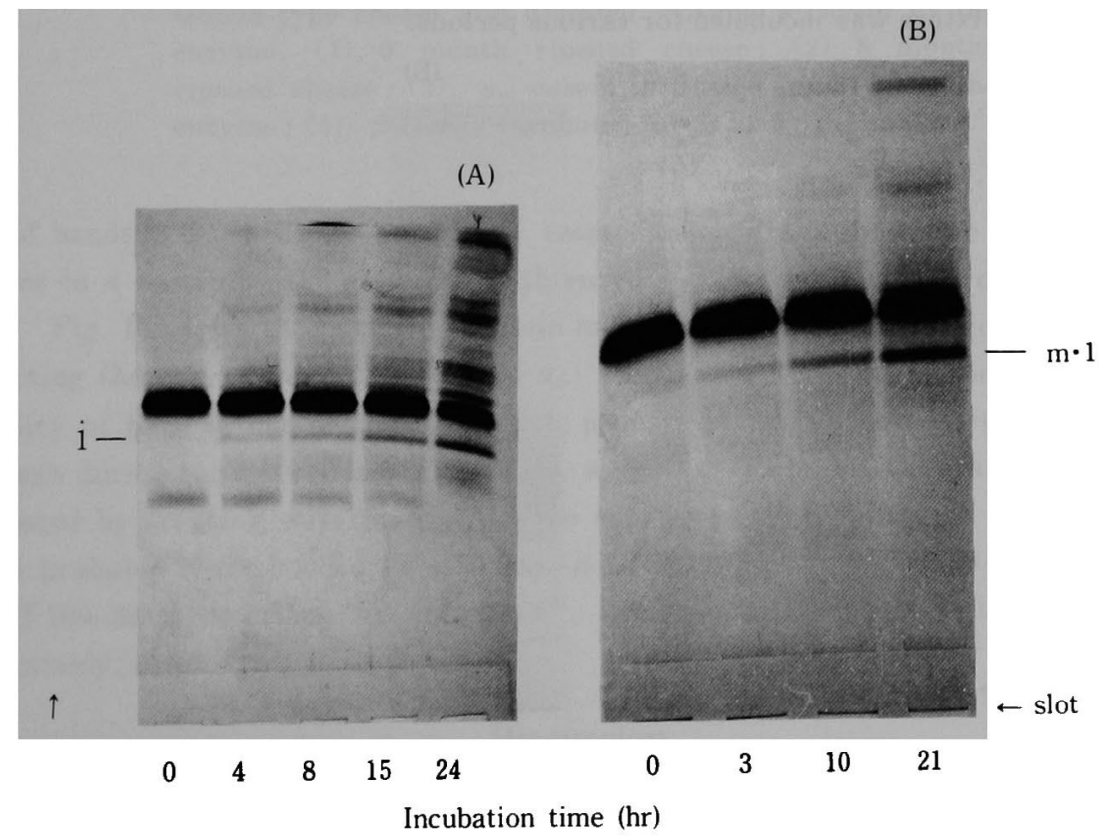

Fig. 7. Changes in PAGE patterns of $\alpha_{\mathrm{s} 1}$-casein by the enzyme (A) and alkaline milk proteinase (B). One $\mathrm{ml}$ of the enzyme solution, dissolved in $0.25 \mathrm{M}$ tris- $\mathrm{HCl}$ buffer, and $1 \mathrm{ml}$ of $0.5 \% \alpha_{\mathrm{s} 1}$-casein solution were mixed and then the mixture was incubated for various periods. 


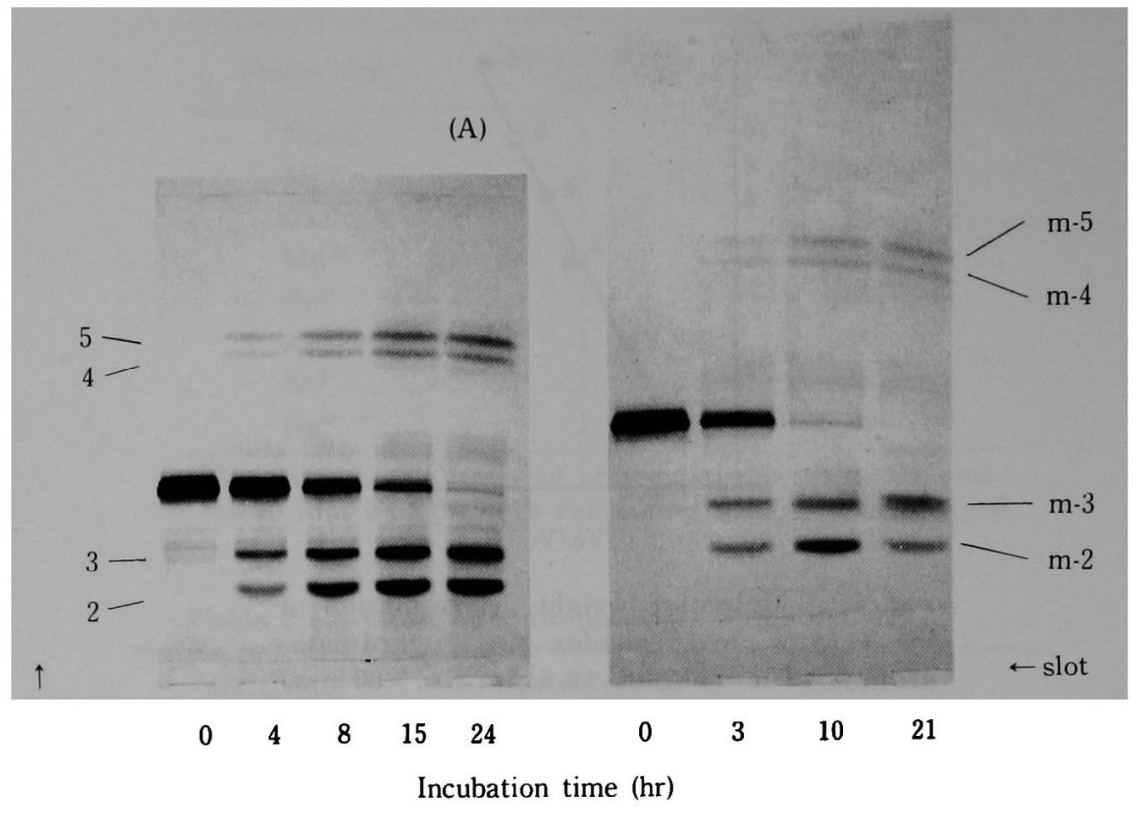

Fig. 8. Changes in PAGE patterns of $\beta$-casein by the enzyme (A) and alkaline milk proteinase (B). One $\mathrm{ml}$ of the enzyme solution, dissolved in $0.25 \mathrm{M}$ tris- $\mathrm{HCl}$ buffer, and $1 \mathrm{ml}$ of $0.5 \% \beta$-casein solution were mixed and then the mixture was incubated for various periods.

(B)

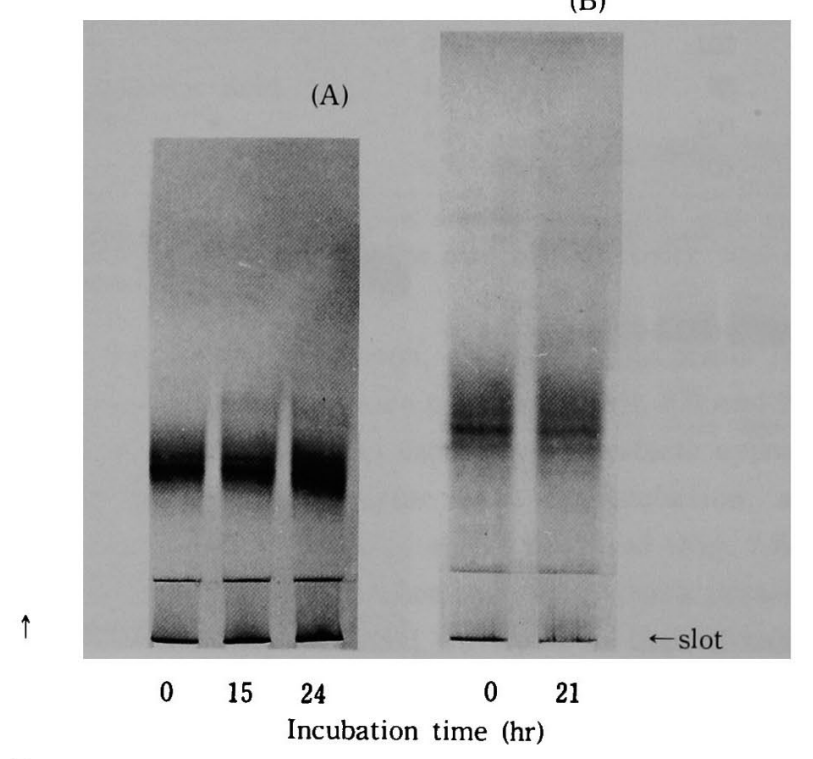

Fig. 9. Changes in PAGE patterns of $\kappa$-casein by the enzyme (A) and alkaline milk proteinase (B). One $\mathrm{ml}$ of the enzyme solution, dissolved in $0.25 \mathrm{M}$ tris- $\mathrm{HCl}$ buffer $(\mathrm{pH} 8.0$ ), and $1 \mathrm{ml}$ of $0.5 \% \kappa$-casein solution were mixed and then the mixture was incubated for various periods. 


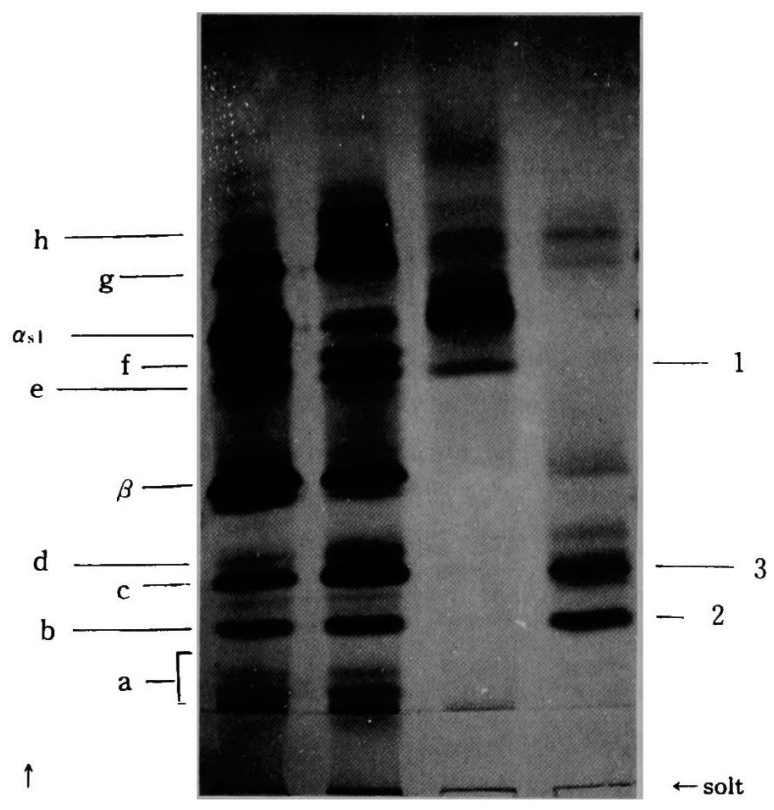

(1) (2) (3) (4)

Fig. 10. PAGE patterns of decomposed products in

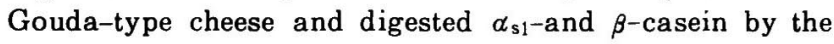
enzyme. (1), 0 month ripened cheese; (2), 5 months ripened cheese ; (3), $\alpha_{\mathrm{s} 1}$-casein incubated for $24 \mathrm{hr}$ by the enzyme ; 4 ), $\beta$-casein incubated for $24 \mathrm{hr}$ by the enzyme.

that of bands $m-2, m-3, m-4$ and $m-5$, respectively. Fig. 9 shows the electrophoretic changes in $\kappa$-casein by the action of both enzymes. $\kappa$-Casein was hardly degraded by them. Fig. 10 shows the pattern of casein in Gouda-type cheese ${ }^{16)}$, which was used for extracting the enzyme, and the digested $\alpha_{\mathrm{s}} 1^{-}$casein and $\beta$-casein by the enzyme. The mobility of band e, one of the proteolytic products which appeared between $\alpha_{\mathrm{s} 1^{-}}$and $\beta$-casein during the cheese ripening process, was equal to that of the fragment (band 1) generated by treating $\alpha_{\mathrm{s}_{1}}$ - casein with the enzyme. The mobility of bands b and c, which probably corresponded to $\gamma$-casein ( $\beta-\mathrm{CN}$ (f 29-209), $\beta$-CN (f 106-209) and $\beta$ CN (f 109-209)) described by CREAMER ${ }^{3)}$, was similar to that of bands 2 and 3 , respectively, originating from $\beta$-casein

\section{Discussion}

As shown in Table 1, the enzyme was purified about 120 fold with a yield of $1.7 \%$ over the extracted fraction. The purified enzyme obtained from rechromatography on CM-Sephadex was subjected polyacrylamide gel electrophoresis, and as shown in Fig. 3 , a single band was detected, indicating that the enzyme was essentially homogenous.

The present enzyme was most active at $\mathrm{pH} 8.0$ and had a temperature optimum at 
about $40^{\circ} \mathrm{C}$, these results being similar to those of alkaline milk proteinase ${ }^{17,18}$. The enzyme was not inhibited by EDTA and $a$ - $\alpha^{\prime}$-dipyridyl, which are metal protease inhibitors, and not by iodoacetic acid and PCMB, which are thiol protease inhibitors. The enzyme was significantly inhibited by TLCK and STI, specific inhibitors of trypsin, but not by ovomucoid and TPCK. These properties are also similar to those of the alkaline milk proteinase reported by CHEN and LEDFORD ${ }^{18)}$ and KAMINOGAWA et al. ${ }^{199}$. With regard to the pH stability and the effect of metal ions on the enzyme activity, this enzyme was similar to the alkaline milk proteinase ${ }^{19)}$.

The molecular weight of the enzyme was approximately 100,000 , this value being equal to the molecular weight of the alkaline milk proteinase reported by DULLEY ${ }^{203}$. On the other hand, KAMINOGAWA et al. ${ }^{19)}$ have shown that the molecular weight of the alkaline milk proteinase was 48,000 , and this value is different from that of the enzyme. The alkaline milk proteinase may probably exist in the form of a dimer.

Changes in the PAGE patterns of $\alpha_{s_{1}}, \beta$ - and $\alpha$-casein by the enzyme were examined and compared with changes in the PAGE patterns of $\alpha_{51^{-}}, \beta$-and $\kappa$-casein by the alkaline milk proteinase (Figs. 7, 8 and 9). These changes in the PAGE patterns of the casein fraction by both enzymes were identical. Changes in the PAGE pattern of $\beta$-casein by the enzyme were the same as those by the alkaline proteinase in milk, and the other enzymic properties of the enzyme were similar to those of the alkaline milk proteinase (Figs. 4, 5 and 6, Tables 2 and 3). These results show that the proteinase purified from Gouda-type cheese in this experiment may be the same as the alkaline milk proteinase.

It is known that some decomposed fragments appear during cheese ripening ${ }^{16)}$. We found these decomposed products (bands a to $h$ in Fig. 10) in Gouda-type cheese. The mobility of bands $b, c$ and $e$ was similar to that of bands 2, 3 and 1, respectively, generated. by treating $\alpha$ s $1-$ and $\beta$-casein with the enzyme. This result shows that the decomposed products in the cheese were resulted from the enzyme isolated in this experiment. It is likely that the proteinase purified from Gouda-type cheese contributes to the proteolysis during cheese ripening.

\section{References}

1) Desmazeaud, M.J. and J.-C. Gripon, Milchwissenschaft, $32: 731-734.1977$.

2) Creamer, L.K. and B.C. Richardson, N.Z.J. Dairy Sci. Tech., 9: 9-13. 1974.

3) Creamer, L.K., J. Dairy Sci., $58: 287-292.1975$.

4) Yamauchi, K. and S. Kaminogawa, Agric. Biol. Chem., $36: 249-254.1972$.

5) Kaminogawa, S. and K. Yamauchi, Agric. Biol. Chem., $36: 255-260.1972$.

6) Kaminogawa, S. and K. Yamauchi, Agric. Biol. Chem., $38: 2343-2348.1974$.

7) Noomen, A., Neth. Milk Dairy J., $32: 26-48.1978$.

8) Visser, F.M.W. and A.E.A. de Groot-Moster, Neth. Milk Dairy J., $31: 247-264$. 1977.

9) Igoshi, K., S. Kaminogawa and K. Yamauchi, J. Dairy Sci., 69:2018-2016. 1986.

10) Ashaffenburg, R., J. Dairy Res., $30: 259-261.1963$.

11) Zittle, C.A. and J.H. Custer, J. Dairy Sci., $46: 1183-1188.1963$.

12) Fox, P.F. and J. Guiney, J. Dairy Res., 39: 49-53. 1972. 
13) Yamauchi, K. and S. Kaminogawa, Jpn. J. Zootech. Sci., $40: 551-558.1969$.

14) O' Farkell, P.O., J. Biol. Chem., $259: 4007-4021.1975$.

15) Reisfeid, R.A., U.J. Lewis and D.E. Willams, Nature, 195: 281-283. 1962.

16) Igoshi, K., H. Kobayashi, S. Kaminogawa and K. Yamauchi, Proc. Fac. Agr. Kyushu Tokai University, $4:$ 105-109. 1985.

17) Kaminogawa, S. and K. Yamauchi, Agic. Biol. Chem., $35: 1465-1467.1971$.

18) Chen, J.H. and R.A. LedFord, J. Dairy Sci., $54: 763.1971$.

19) Kaminogawa, S., H. Mrzobuchi and K. Yamauchi, Agric. Biol. Chem., $36: 2163-2167$. 1972.

20) Dullzy, J.R., J. Dairy Res., 39 : 1-9. 1972.

ゴーダタイプチーズより得られる至適 $\mathrm{pH} 8.0$ のプロティナーゼ の精製と性質ならびにミルクプロティナーゼとの比較

山内邦男・井越敬司 ${ }^{*} \cdot$ 上野川修一

東京大学農学部, 東京都文京区 113

*九州東海大学晨学部, 能本県長陽村 869

ゴーダタイプチーズ槃成中の蛋白質分解に関与するフ ロティナーゼを，硫安垣析， $\mathrm{CM}$ 一つフデックスクロ マトクラフィーおよび DEAE-セルロースクロマトグ ラフィーにて精幣した。得られた精製䤕素はポリアクリ ルアミトゲル電気泳動で調べた結果, ほぼ均一であり, またその至道 $\mathrm{pH}$ は 8.0であった. 本䣼菜は DFP, TLCK および STI で阻害されるところからトリプシン 様醉莱亡推定され，またその分子量は 100,000 と見積す られた，本䤃素をカぜイン成分に作用させ，その分解性
について電気泳糼を用いて調べた．その結果， $\boldsymbol{\alpha}_{\mathbf{a}}$-カゼ インからはいくつかの分解産物が出現し，また $\beta$-カゼ インからは $\gamma$-カゼインと移動度を同じくする成分の出 現か認められた。

以上の本醇秦の性䁈は牛乳中のアルカリプロティナー ぜとよく似ていた，従って，本醉素は牛乳中のアルカリ プロティナーゼそのすのと㤗えられた.

日畜会報，58(6)：516-527，1987 